\title{
Semi-Natural Areas on Post-Mining Brownfields as an Opportunity to Strengthen the Attractiveness of a Small Town. An Example of Radzionków in Southern Poland
}

\author{
Iwona Kantor-Pietraga ${ }^{1, *} \mathbb{1}$, Aleksandra Zdyrko ${ }^{2}$ and Jakub Bednarczyk ${ }^{2}$ \\ 1 Institute of Social and Economic Geography and Spatial Management, Faculty of Natural Sciences, \\ University of Silesia in Katowice, Będzińska 60, 41-200 Sosnowiec, Poland \\ 2 Faculty of Natural Sciences, University of Silesia in Katowice, Będzińska 60, 41-200 Sosnowiec, Poland; \\ aleksandrazdyrko@gmail.com (A.Z.); jakub.kubek.bednarczyk@gmail.com (J.B.) \\ * Correspondence: iwona.kantor-pietraga@us.edu.pl
}

check for updates

Citation: Kantor-Pietraga, I.; Zdyrko, A.; Bednarczyk, J. Semi-Natural Areas on Post-Mining Brownfields as an Opportunity to Strengthen the Attractiveness of a Small Town. An Example of Radzionków in Southern Poland. Land 2021, 10, 761. https://doi.org/10.3390/land10070761

Academic Editors: Oimahmad

Rahmonov, Jacek Róźkowski and Grzegorz Kłys

Received: 11 June 2021

Accepted: 16 July 2021

Published: 19 July 2021

Publisher's Note: MDPI stays neutral with regard to jurisdictional claims in published maps and institutional affiliations.

Copyright: (c) 2021 by the authors. Licensee MDPI, Basel, Switzerland. This article is an open access article distributed under the terms and conditions of the Creative Commons Attribution (CC BY) license (https:/ / creativecommons.org/licenses/by/ $4.0 /)$.

\begin{abstract}
The socio-economic and political changes of the end of the 20th century in Central and Eastern Europe had significant impacts on the transformation of urban spaces, especially in industrial and mining towns. The article attempts to explain the essence of these changes concerning the spatial development of - a small post-mining town in southern Poland. This article evaluates urban development policy in response to the significant land-use changes in the small post-mining city of Radzionków, with particular attention to the transformation of brownfield sites to semi-natural areas of regional importance. This issue is interesting for two reasons. First, this small city, located in a large European agglomeration, has to face competition focused on interesting regional projects. Second, there is a desire for reindustrialization as a remedy for job losses in mining and heavy industry. The successful establishment of a large botanical garden in this city provides a case study for discussing the future of small post-industrial cities and the development of land use policy regarding valuable natural areas located in post-industrial and post-mining areas. This study also indicates the vital role of the creative management factor.
\end{abstract}

Keywords: post-mining areas; brownfields; land use planning; Silesian Botanical Garden; Radzionków

\section{Introduction}

The transformation of cities has many faces. The phenomena which dynamize these changes are always a unique challenge, especially if they have a dimension of regressionsocial, economic, or spatial. Combining these elements creates a problematic situation that leads to urban shrinkage [1-5]. Demographic decline, which is the most common definition criterion in cities of this type, is usually only one of many aspects of changes that constitute a vital message for local and regional urban policy [6-8].

Complicated cases of regress of cities are related to previous perturbations in the economic sphere [9]. In most cases, urban shrinkage is related to deindustrialization. Apart from the economic consequences, it also has a social dimension (increased unemployment, increased poverty, or social exclusion). In turn, in the spatial dimension, these are problems with the management of post-industrial brownfields. Brownfields are spaces that negatively affect the perception of the city.

The problems of a shrinking post-industrial city are a unique challenge, especially when an industrial plant which is the only large enterprise in the city is closed. The chance of substituting the current economic potential, at least in terms of the resilience of the local labor market, especially in the first years after the liquidation of this company, is relatively small [10].

The second aspect that strengthens the problems of a post-industrial city is its size. Undoubtedly, small towns are in the most challenging situation [11,12]. In this case, there is 
a specific marginalization or even hibernation of socio-economic structures. They begin to resemble those in the (rural) environment or create a characteristic problem funnel (niche) in locations within larger agglomeration cities. One such case of the latter type of city is Radzionków in southern Poland. After the closure of a large hard coal mine, the city faced significant functional, social, and spatial challenges [13]. It is the spatial challenges that are the subject of the research in this article.

The article aims to evaluate the success of planned semi-natural areas of regional importance in a small post-mining town.

On the one hand, the above assumption relates to the subjectivity of semi-natural areas, indicated by the concept of green infrastructure (GI) [14]. As emphasized by Wirth et al. [15], the GI concept "focuses on the connectivity of urban green space, aims at multifunctionality, forges a link to the spatial provision of ecosystem services and highlights the need for close collaboration between scientific, political and administrative actors" (p. 79).

On the other hand, this assumption relates to the project of the Silesian Botanical Garden implemented in the small town of Radzionków, located in the area of the former ore mining. This investment proves that post-industrial areas are potential green areas [15-19]. The creation of the garden as an interesting attraction in southern Poland strengthened efforts to eliminate the effects of the socio-economic transformation of Radzionków. This question is related to a slightly broader dilemma concerning the directions of spatial development in post-mining towns, as expected in their revitalization process [20-22]. An aspect of urban regeneration is brownfield redevelopment, which has recently become an essential sustainable land-use strategy [23].

The article consists of an Introduction, Research Review, a chapter on data and methods, three thematic chapters, and Discussions and Conclusions. The following thematic chapters present: the history of the development of the small town of Radzionków on the way from industrialization to post-mining, then the directions of development of post-industrial and post-mining areas in Radzionków, and the importance of the Silesian Botanical Garden in Radzionków compared to other natural objects in the studied region.

\section{Research Review}

Developing post-mining areas in small towns can be considered within the framework of several existing scientific discourses. Considering the research objective and the specific case of the city of Radzionków, attention should be paid first of all to four essential discourses:

- a small industrial or mining town after the loss of its function,

- inter-city competition for investments in the context of local and regional policy,

- urban shrinkage and brownfields development,

- green infrastructure.

The scientific achievements of small post-industrial towns are already significant [12,24]. The essence of research in this area focuses primarily on diagnosing the situation in this city after losing the existing functions. The research concerned post-industrial and post-mining cities $[25,26]$. Regardless of the type of earlier conducted economic activity, attention must be paid to the emergence of negative and multi-faceted consequences of breaking the existing functional and social ties. In addition, in post-mining towns, special attention is paid to problems related to the rehabilitation of degraded areas [27-30]. An essential issue in the research is the conclusion on the support of transformation by entities and institutions located at various levels of administration. For most such cities, which are usually affected by a multi-faceted crisis, challenges related to revitalization $[31,32]$ and finding a new development path are too big [33,34]. Nevertheless, it should be noted that the emergence of problems with finding new functions for post-mining areas triggers a social need for change and transformation. These changes are based, on the one hand, on the principles of spatial planning and regional policy of a given country, and on the other hand, on a specific imbalance between social and economic needs [35-37]. 
Researchers are considering post-industrial and post-mining cities in terms of opportunities and threats standing in the way of exit with new unfavorable conditions [38-40]. Among these threats is competition between cities, resulting from location and proximity to other cities, especially larger ones [41-43]. On the one hand, small towns located in the vicinity of the larger ones are an opportunity for some residents looking for a quieter place to live. In Poland, small towns in the vicinity of larger ones are beneficiaries of the suburbanization process, similarly to formal rural communes [44,45]. However, when analyzing in detail the migration processes in the vicinity of large cities, it can be seen that the migration inflow to some cities from the core cities is relatively limited. A more detailed analysis shows that these are most often small post-industrial cities [46].

When analyzing the discourse on urban shrinkage globally, one should also pay attention to some differences in the approach to this problem, especially in the period up to 2010. In North America or Asian countries, much attention has been paid to demographic and social issues, while in the European debate, especially concerning Central and Eastern Europe, economic issues were a key element, emphasizing reindustrialization [47-51]. In Central and Eastern Europe, such an approach undoubtedly resulted from economic and financial constraints on implementing social policies [8,52,53]. The exception was former East Germany, where the federal government's support significantly enabled urban and social modernization plans (Stadtumbau Ost) [54-56]. It also seems that Polish cities are part of the pan-European trend of striving for the socio-liberal sustainability of the city, while, for example, American cities develop as spaces stimulated by free-market land rent [49,52].

The problem of small post-industrial cities, including those in the vicinity of metropolises, is primarily related to their perception [10]. Undoubtedly, in addition to social problems, spatial development issues, especially the existing brownfields [57-59], also exist in small towns [12]. From the point of view of the article's aim, publications devoted to brownfield development aimed at restoration and, on the other hand, at tourism and recreational functions are significant. In publications on renaturalization, researchers focus primarily on biodiversity and ecosystem services [60-65]. On the other hand, research devoted to the transformation of brownfields towards tourist and recreational functions draws attention to the opportunities offered by new functions of a town in the process of economic, social, and spatial renewal of a city or region [66-69].

However, as Wirth et al. [15] indicated, the concept of ecosystem services has less explanatory value about the post-mining areas. These researchers believe that the concept of green infrastructure (GI) explains these issues much better [14,70]. This concept indicates such attributes as:

- integration,

- multifunctionality,

- connectivity,

- multi-scale approach,

- multi-object approach [15].

The conclusions from research concerning other regions also confirm these assumptions [71-74].

The concept of green infrastructure reflects the reality analyzed in the article well for two reasons. First, as mentioned, it captures the specificity of post-mining areas. Second, it applies to land-use planning, pointing to natural and semi-natural areas.

\section{Data and Methods}

Various types of data have been used in this article. The most important were cartographic sources, planning and strategic documents, publications on the development of Radzionków, and the management of post-industrial areas. Historical maps were used in the first stage of the research. Sheets of digital historical maps, or Messtischblatt, made it possible to prepare a map showing the former industrial and mining areas: sheets 5579-Tarnowitz issued in 1940 and 1943 on the scale of 1:25,000 in the Gauss-Krüger projection [75,76] and sheets 5679-Beuthen issued in 1934 and 1943 on the scale 1:25,000 
in the Gauss-Krüger projection $[77,78]$. These sources give the location of significant plants along the main roads of the city of Radzionków, where the first settlement and then the center of Radzionków developed.

Former and contemporary types of land use have been studied with modern digital materials and tools. In order to determine the type and directions of land development, the metadata of the Corine Land Cover 2018 PL program was used [79]. In contrast, land cover and land use information comes from the Urban Atlas 2012 Copernicus Land Monitoring Service [80].

It was necessary to verify and update the data thoroughly. Data update (H2 2020) was carried out based on Google Maps [81], OpenStreetMap [82], satellite photos, and Geoportal 2 Maps [83]. Comparing elements from different sources made it possible to create the most up-to-date picture of the development of post-industrial and post-mining areas of the city of Radzionków.

In addition, in the Silesian Botanical Garden in Radzionków, a data inventory in the field was carried out using Leica GPS. We also explored the area of Radzionków using a DJI Phantom 4 Advanced drone.

The collected historical data was georeferenced and then analyzed by comparing the overlapping layers. Attribute tables have been created for each layer, containing the land use data for a specific year-detailed analysis of statistical data allowed analysis of the development of post-industrial and post-mining areas. An essential part of the research was the use of cartographic methods that enabled the development of maps. The maps were created based on ArcMap software and Open Source QGIS software.

We used various research methods to study land-use changes in Radzionków and the area of the Silesian Botanical Garden. The first was analyzing historical materials and using GIS tools and DJI Phantom 4 Advanced drone analysis. These materials prompted field research carried out in places where post-industrial and post-mining activities we previously found. A detailed inventory was carried out mainly in the area of the Silesian Botanical Garden in Radzionków.

Then, all field data, drone records, and other cartographic, statistical, and planning materials were verified based on spatial analysis methods and the existing concepts of changes in spatial development, especially in post-industrial and post-mining areas.

Emerging problems required solutions during the analysis. When assigning a coordinate system for historical map sheets in the form of numerical maps, we had to use the Georeference tool in ArcGIS Pro. This tool made it possible to adjust the sheets to the coordinates in the target WSG 84 reference system and to compare them with materials such as OpenStreetMap, Corine Land Cover, or Urban Atlas. Such adjustment is the best and fastest solution for large-scale development when we can use ESRI software. In both QGIS and ArcMap, it is not possible to move the map with the cursor. It is possible only when entering points of the coordinate system by oneself. It should also be noted that historical map sheets were often deliberately deformed to hide significant strategic points. As a result, with a perfect match of one point, the point on the opposite side of the map may be significantly shifted. ArcGIS Pro made it possible to partially circumvent the problem with the coordinate system for Messtischblatt maps. In the Gauss-Krüger projection, where the Bessel ellipsoid was used as a model of the Earth, the territory of the Third Reich is divided into six zones. For the area of today's Poland, these are zones 5 and 6 . The map sheets that comprise zone 5 have the coordinate system entered within the framework of GIS programs. On the other hand, zone 6, in which the tested Radzionków is located, is much more troublesome, as it requires entering the definition of zone 6 manually: "+ Proj $=$ tmerc + lat $\_0=0+$ lon $\_0=18+\mathrm{k}=1+\mathrm{x} \_0=6,500,000+\mathrm{y} \_0=0+$ ellps $=$ bessel + datum $=$ potsdam + units $=\mathrm{m}+$ no_defs".

Thanks to this action, it was possible to locate the appropriate sheets in the coordinate system and later analyze the spatial development of the Radzionków area.

Analysis steps for ArcGIS Pro:

1. Addition Messtischblatt sheets to the project. 
2. Launching the "georeference" tool.

3. Shifting the map sheets to the right place (you can enlarge/reduce the map), OSM can be used as a base map, historical sheets can match.

4. Saving changes and close georeference.

5. Exporting the spreadsheet as a. Tiff file-now the file is georeferenced and can also be used in other GIS programs.

6. Cutting sheets with the "Clip" tool to the commune border.

7. Matching the cut map sheets to each other and the base map (optional raster combination).

8. Superimposing the data to compare the map (CLC, UA, OSM) on the finished raster.

\section{The Small Town of Radzionków on the Way from Industrialization to Post-Mining}

Radzionków is a small town (urban commune) located in the Katowice conurbation in southern Poland (Figure 1). The history of this mining town dates back to the 14th century. The oldest documentation describing Radzionków as a thriving mining settlement comes from that time. The 19th century was a turning point in the town's development, as in 1801, the industrialization process of Radzionków began as a result of the establishment of the Antonina zinc smelter [84]. In 1845, there were as many as 20 metal ores mining shafts in Radzionków. Another important event in the development of Radzionków's industry was the opening of the Radzionków hard coal mine in 1871 (first extraction in 1874). In 1884, the Łazarz zinc smelter was established near the mine, producing sulfuric and hydrochloric acid. These events changed the face of the city and shaped its mining character [85]. At that time, quarries, extracting raw material for limestone kilns, began to appear. The largest of them is the "Maciej" quarry on Księża Góra. The development of industry was related to the creation of railroads (1870) and two railway stations, a post office (1882), a water supply (1904), and the electrification of the settlement (1908). In the second half of the nineteenth century, the Mathias mine was established, extracting calamine located in Księża Góra [86]. After the extraction of all the raw material on the slope of Księża Góra, exploitation of limestone deposits began.

In the 20th century, Radzionków developed primarily as a town associated with the exploitation of hard coal. The exploitation of rock raw materials, especially after World War II, has been marginalized. Until the 1990s, Radzionków was a typical mining town related to one large coal mine. In the years 1975-1997, Radzionków was periodically attached to the neighboring large city of Bytom as one of its northern districts. In turn, the Radzionków Hard Coal Mine was closed in 1995, and the work was completed entirely in 2000. The closure of the mine resulted in unfavorable economic and social changes in the city [87]. The number of unemployed increased, the mining school was closed, and many former miners aged 40-50 were on bridging leaves. The city "compensated" the liquidation of the coal mine by regaining administrative independence as a so-called restored city [86], which allowed for more appropriate management of the budget of the post-industrial city. The large neighboring city of Bytom had similar problems with deindustrialization, and Radzionków was only one of the peripheral districts in it. Radzionków is adjacent to three towns (urban communes): Bytom, Piekary Śląskie, Tarnowskie Góry. Table 1 also shows that Radzionków, compared to the neighboring cities, coped relatively well with the depopulation common in the region. Tarnowskie Góry is medium-size town localized in the outer zone of conurbation as a center of suburban processes. Radzionków represents the same type but as an example of a small town. In both cases, the visible edges (core/outer zone) location reduces the scale of the demographic loss so visible in the core cities (Bytom, Piekary Śląskie). 
Table 1. Dynamics of the population in Radzionków and neighboring towns in 2000-2019.

\begin{tabular}{cccccccc}
\hline \multirow{2}{*}{ Town } & \multirow{2}{*}{ Area in ha } & \multicolumn{3}{c}{ Population in Total } & \multicolumn{2}{c}{ Dynamics of the Population in \% } \\
\cline { 3 - 7 } & & $\mathbf{2 0 0 0}$ & $\mathbf{2 0 1 0}$ & $\mathbf{2 0 1 9}$ & $\mathbf{2 0 0 0 - 2 0 1 0}$ & $\mathbf{2 0 1 0 - 2 0 1 9}$ & $\mathbf{2 0 0 0 - 2 0 1 9}$ \\
\hline Radzionków & 1320 & 17,533 & 17,169 & 16,873 & -2.08 & -1.72 & -3.76 \\
Bytom & 6944 & 195,807 & 181,617 & 165,263 & -7.25 & -9.00 & -15.60 \\
Piekary Śląskie & 3998 & 61,347 & 58,268 & 55,030 & -5.02 & -5.56 & -10.30 \\
Tarnowskie Góry & 8388 & 62,764 & 60,818 & 61,686 & -3.10 & 1.43 & -1.72 \\
\hline
\end{tabular}

Source: own elaboration on the base of [88].

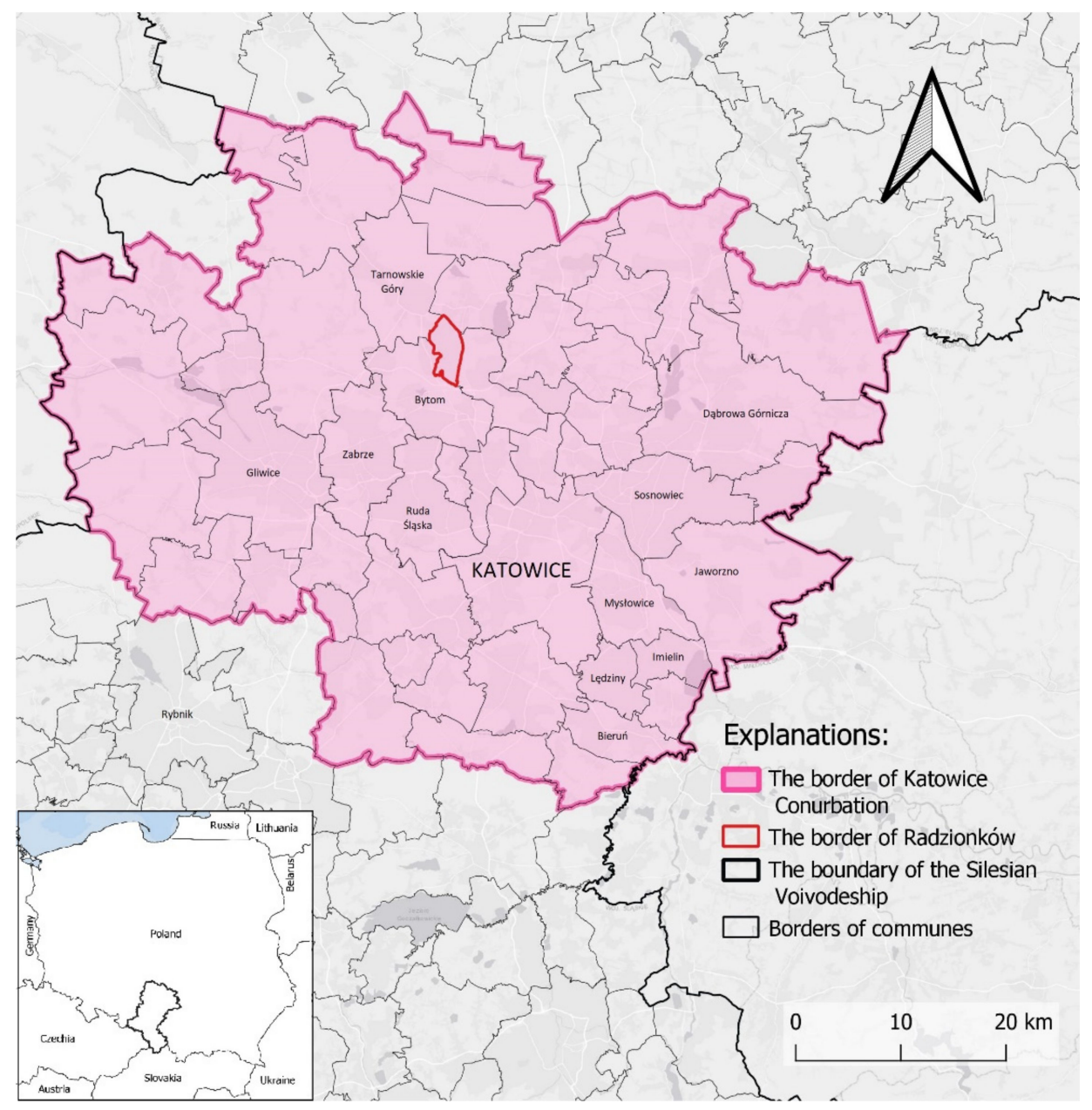

Figure 1. Location of Radzionków. Source: own study using the Topographic Objects Database [89].

Today, Radzionków is a city developing in the industrial and service sector. Many local companies have been established here, especially in the service sector and new industries [13]. It is worth noting that the city has unique places in the region, but also the whole country, such as the Museum of Bread, the Center for Documentation of the Deportation of Upper Silesians to the USSR in 1945, the Silesian Botanical Garden, and the Regional Station of Ecological Education. A Study on Conditions and Directions of Spatial Development of the Radzionków Municipality focuses on shaping the city through investments of supra-regional importance [90].

The reindustrialization process significantly improved the situation in the labor market in Radzionków, which translated into a gradual improvement in the city's image. The city authorities pursue an effective policy development of post-industrial and post-mining areas. Radzionków strengthens its position as a service city and focuses on the development 
of tourism and recreation [91]. There are also initiatives aimed at creating a rich offer of various activities, including occasional cultural events.

Currently, Radzionków is a city that aims to provide its inhabitants with the best possible standard of living. The city authorities are trying to diagnose and eliminate existing social problems, such as unemployment, poverty, homelessness, and health hazards [92].

It is also essential to pay attention to the concentration of the population, which in the case of Radzionków is largest in the city center (its central district). With a high population concentration, it is challenging to eliminate low emissions from domestic stoves. In addition, it is not very easy to eliminate emissions among the inhabitants who worked in the mining industry and thus had coal allowances [93]. Therefore, the protection of the natural environment is an essential direction of development. One example is the revitalization of the Szarlejka river at the southern border of Radzionków [94].

It is also worth paying attention to the main strategic goals of Radzionków, such as an intelligent economy; it is connected, among other things, with the improvement of communication conditions, with particular emphasis on commuters [95]. The second goal is to create a friendly urban space by enhancing the city center's attractiveness, revitalizing urban spaces, or shaping urban landscapes [96,97]. A third goal is a suitable place of residence. It is supposed to contribute primarily to strengthening the Silesian values of the local community [98] and improving the accessibility to new and existing public services by maintaining the city's culture.

Socio-economic changes in Radzionków in the 1990s and their continuation in the following decades resulted, among other effects, in the formation of derelict lands. Quite quickly, this problem, apart from depopulation, became one of the city's key challenges [13].

\section{Directions of Development of Post-Industrial and Post-Mining Areas in Radzionków}

Invested areas constitute a large part of the spatial development of Radzionków (Table 2): residential and service facilities areas, industrial areas, communication areas, and technical infrastructure areas (33.82\%). The large share of agricultural land attracts attention. The peripheral location of the city within the entire agglomeration may be the reason for this. The edge location of the city on the border of a highly industrialized and urbanized zone and a peripheral zone with a large share of agricultural land was of significant importance in the genesis of the later landscapes. On the one hand, these were industrial and mining areas typical of the core of the entire urban region. On the other hand, open pits of raw materials other than hard coal are often located in the peripheralagricultural zone. This dual process of derelict land formation is visible on this type of area (Figure 2).

The general principles of spatial development in the Radzionków area concerning post-industrial and post-mining areas indicate that these are areas preferred for new investments. However, the areas are more varied. Table 3 presents a detailed share of land use in post-industrial and post-mining areas and their previous use. It shows that most areas are covered by sports and recreation areas, including the Silesian Botanical Garden $(4.77 \%)$ and forests $(4.08 \%)$. As for a highly urbanized urban conurbation area, relatively small areas are designated for reindustrialization $(2.27 \%)$ and the location of residential buildings $(0.63 \%)$. Derelict lands cover a total of $15.52 \%$ of the area of Radzionków.

Among the activities related to the reindustrialization of brownfields, the most important is land development after liquidated large industrial plants. Currently, in the post-industrial areas of two large industrial plants (KWK Radzionków and the former Huta Łazarz) located in the southern part of the city, there is an activity in the waste recycling industry (Wtórmet Radzionków sp. z o.o.) and the fuel industry (TanQuid Polska sp. z o.o.). A completely different direction of changes in the spatial development of the heap of the former Łazarz Huta was adopted. It is supposed to be an area of recreation and rest, as recorded in A Study on Conditions and Directions of Spatial Development of the Radzionków Municipality [90]. 
Table 2. Land-use type in Radzionków.

\begin{tabular}{ccc}
\hline Land-Use Type & Area in ha & Area in \% \\
\hline Residential areas & 160.80 & 12.16 \\
Industrial areas & 58.10 & 4.39 \\
Service facilities areas & 113.19 & 8.56 \\
Communication areas & 103.45 & 7.83 \\
Technical infrastructure areas & 11.63 & 0.88 \\
Managed greenery & 22.72 & 1.72 \\
Commercial orchards and gardens & 85.42 & 6.46 \\
Private allotment gardens & 31.66 & 2.39 \\
Managed forests & 89.87 & 6.80 \\
Unmanaged vegetation & 251.88 & 19.05 \\
Agricultural land & 377.62 & 28.56 \\
Lakes and surface reservoirs waters & 3.33 & 0.25 \\
Others & 12.46 & 0.95 \\
Total & 1322.13 & 100.00 \\
\hline
\end{tabular}

Source: own study based on [90].

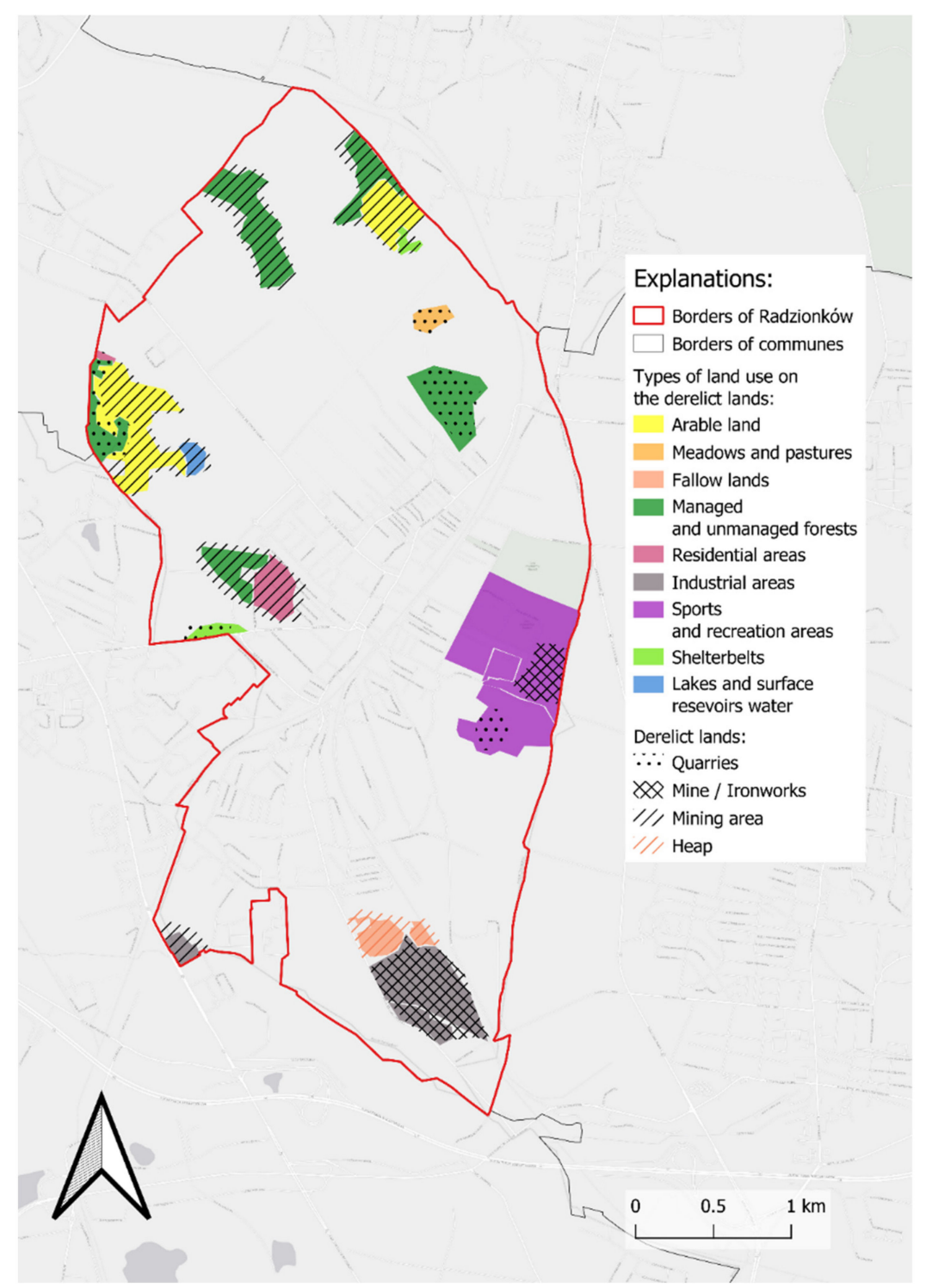

Figure 2. Directions of use of post-industrial and post-mining areas in the Radzionków commune. Source: own study based on [75-83]. 
Table 3. Share of land-use type on post-industrial and post-mining areas in the total town area.

\begin{tabular}{|c|c|c|c|}
\hline \multirow{2}{*}{ Land-Use Type } & \multicolumn{2}{|c|}{ Reclaimed Area } & \multirow{2}{*}{ Previous Use } \\
\hline & ha & $\%$ of Total & \\
\hline Arable land & 33.77 & 2.55 & Mining areas \\
\hline Meadows and pastures & 3.08 & 0.23 & Mining areas \\
\hline Fallow land & 6.93 & 0.52 & The areas of the Radzionków Mine and Huta Łazarz \\
\hline Managed and unmanaged forests & 53.94 & 4.08 & Mining areas/Quarry \\
\hline Residential areas & 8.32 & 0.63 & Mining areas \\
\hline Industrial areas & 30.03 & 2.27 & $\begin{array}{c}\text { Mining areas/The areas of the Radzionków Mine } \\
\text { and Huta Łazarz }\end{array}$ \\
\hline Sports and recreation areas & 63.08 & 4.77 & Quarry/Glider airfield/Księża Góra Park \\
\hline Shelterbelts & 3.83 & 0.29 & Mining areas \\
\hline Lakes and surface reservoirs waters & 2.37 & 0.18 & Mining areas \\
\hline Total & 205.35 & 15.52 & \\
\hline
\end{tabular}

Source: own elaboration.

The development of the area of Księża Góra increased the investment attractiveness in the real estate sector in the immediate vicinity. Changes in the spatial development in this area contributed to creating new estates of single-family and terraced houses on Ogrodowa and Botaniczna streets (Figure 3A,B). This process has intensified since the beginning of work on establishing a branch of the Silesian Botanical Garden. These areas are primarily sub-urbanized in the sub-regional dimension [99,100]. A place that strongly develops residential functions is also the area at the northern border of the Księża Góra park. An additional value attracting new residents is new housing estates on the slopes of the hill mentioned above. It is attractive to admire the panorama of the neighboring town, Piekary Ślaskie. Residential buildings also appeared in the former mining areas-at the present Unii street. This area has also been developed for allotment gardens and as a forest area.
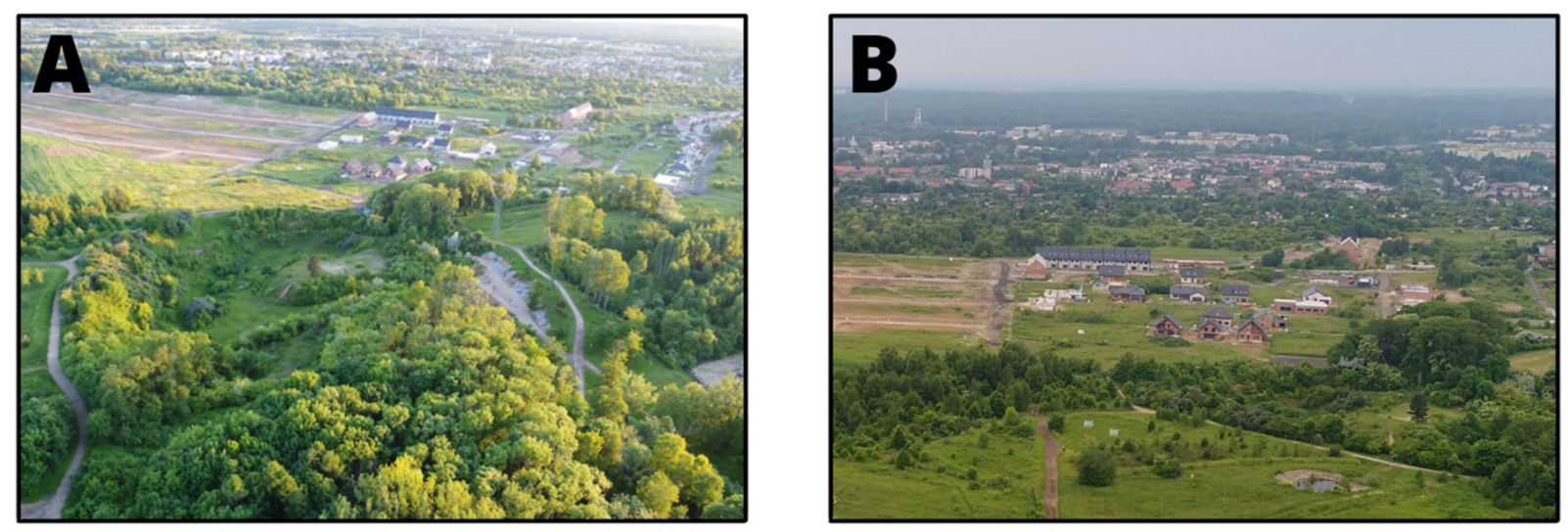

Figure 3. (A,B). New housing estates near the southern border of the Silesian Botanical Garden (photos from 9 June 2021). Source: own photos.

As already mentioned, the central direction of policy changes in brownfields in Radzionków is afforestation and the creation of park space with a recreational and educational function. This direction of changes applies to the Księża Góra region developed as a park area, sports and recreation, education, and the Silesian Botanical Garden. A similar direction of changes also applies to the "Szkała" area of the former quarry, a forest area. In the planning documentation, it is an area undergoing revitalization, intended for recreation. The limestone kilns located at the northern border of the city of Radzionków have also been subject to reclamation activities. It is a recreational and leisure area.

Creating the development of post-mining areas in Radzionków has several key stakeholders. The most important are the city authorities that set the directions of the spatial 
policy. Undoubtedly, an essential advantage of the city is the creative person of the city mayor, whose education refers to strategic management in the local government [13]. Local entrepreneurs are the second most important group in brownfield management. The effectiveness of cooperation with municipal authorities is sound. This is visible, for example, by the fact that most of the post-industrial and post-mining areas have undergone the stage of reindustrialization of the location of new service and logistics companies. The third most important stakeholder is the management of the Silesian Botanical Garden. As mentioned, the Silesian Botanical Garden in Radzionków is a branch of the park in Mikołów.

The distance between the objects and, on the other hand, the proximity causes the synergy effect and the possibility of soliciting a different group of visitors. Scientific institutions from the region also cooperate with the Silesian Botanical Garden. Notably, the inhabitants appreciate the different directions of brownfield development, especially their use for managed forests. The limited financial resources, for example, for better promotion, are probably a problem for the described model of governance.

The development policy of the post-mining areas in Radzionków is exemplary, especially in creating semi-natural areas. However, it is best described by the concept of green infrastructure, an example of which is the Silesian Garden Botanical.

\section{The Silesian Botanical Garden in Radzionków, in Comparison with Other Similar Natural Objects in the Region}

The Silesian Botanical Garden consists of two gardens that have a joint administration. There is the central garden in Mikołów and its branch in Radzionków. The Silesian Botanical Garden in Radzionków has been operating since 2015 on the former limestone open pit and in the vicinity of the former Mathias (Maciej) mine shafts. Due to the varied topography and the remains of the mine in settling old shafts, this area was very problematic for the commune authorities. An additional problem of this previously undeveloped area was the high-voltage line that ran here, making it impossible to implement some potential investments. It was only in 2009 that the Radzionków commune and the Silesian Botanical Garden in Radzionków signed an agreement to establish a botanical garden-Silesian Botanical Garden in Radzionków [101] in Księża Góra. The following year, on 14 October, the General Director of Environmental Protection issued a permit to construct the Botanical Garden. Thus, it is one of the youngest facilities of this type in Poland. The following figure shows the Silesian Botanical Garden in Radzionków in Księża Góra, compared with other similar natural objects in the region (Figure 4).

The Silesian Botanical Garden in Radzionków covers an area of 16 ha (Figure 5A). In addition to the Botanical Garden itself, the Regional Ecological Education Station was established here, which manages the garden, conducts activities in education, and organizes many local events (Figure 5B). The implemented projects attract the local community and residents from other towns in the Katowice conurbation. An important issue is scientific and research cooperation between the Botanical Garden and the Polish Academy of Sciences. The Silesian Botanical Garden in Radzionków has many valuable plant collections. The thematic collections section includes a collection of garden plants, flower meadows, an ericarium, a rosarium, a dendrological collection, and an orchard collection (Figure 5C). Figure 6 presents a detailed share of individual forms of land use of the Silesian Botanical Garden.

On the other hand, the section of the habitat collections consists of forest and trees, thermophilic grasslands and thickets, meadows and marshes, and a heath. It is worth emphasizing that the revitalization of this area required much work. Until the beginning of the 1940s, the entire Księża Góra and the adjacent area were utterly devoid of trees due to intensive industrial activity. Only as a result of social campaigns by the inhabitants was it decided to reforest Księża Góra (Figure 5D). The head of Radzionków, Jerzy Ziętek, also contributed to the creation of the park there. Interestingly, the trees planted at that time were consistent with the vegetation initially found in this area. 


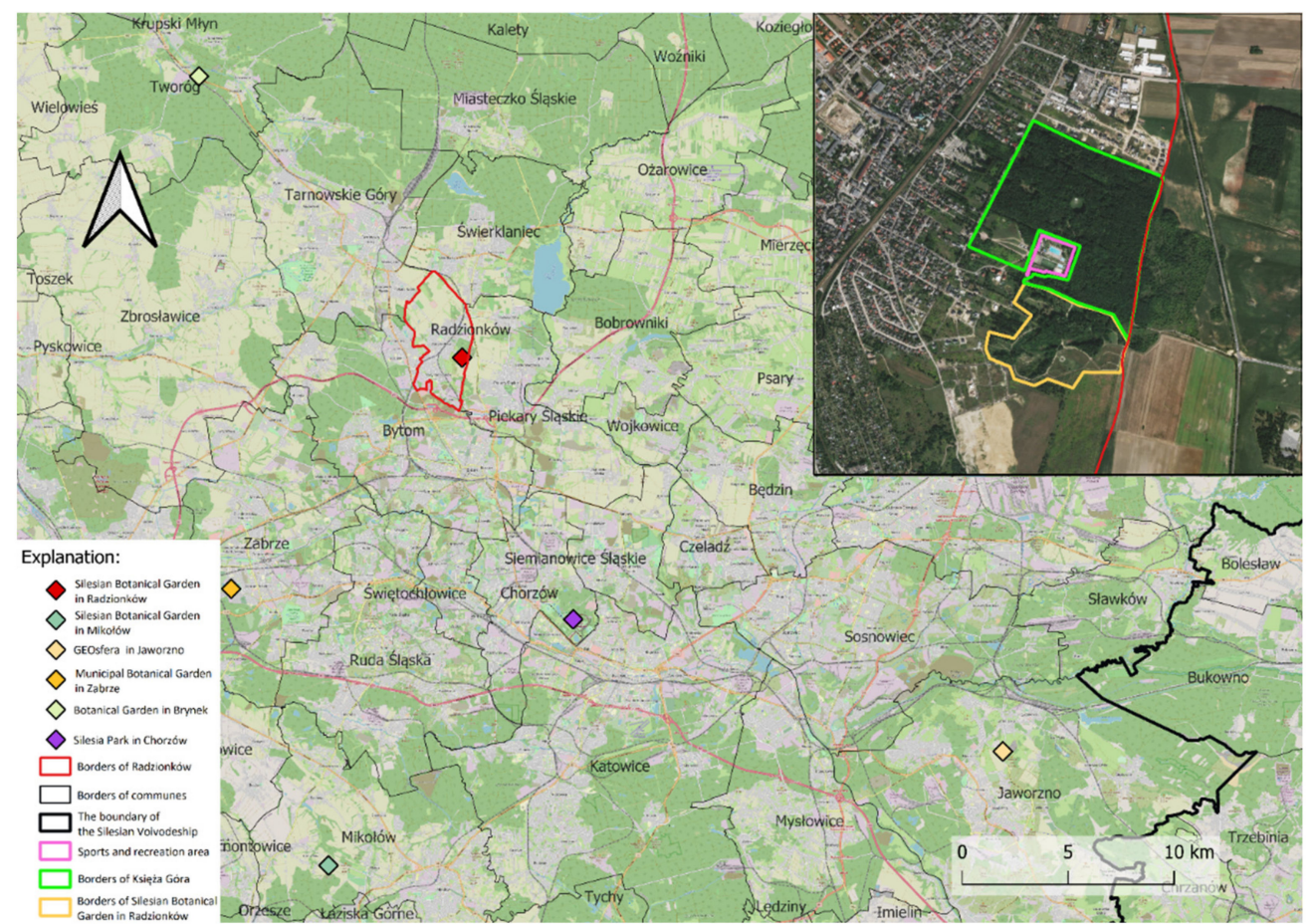

Figure 4. The Silesian Botanical Garden in Radzionków, in comparison with other similar natural objects in the region. Source: own study based on [82].
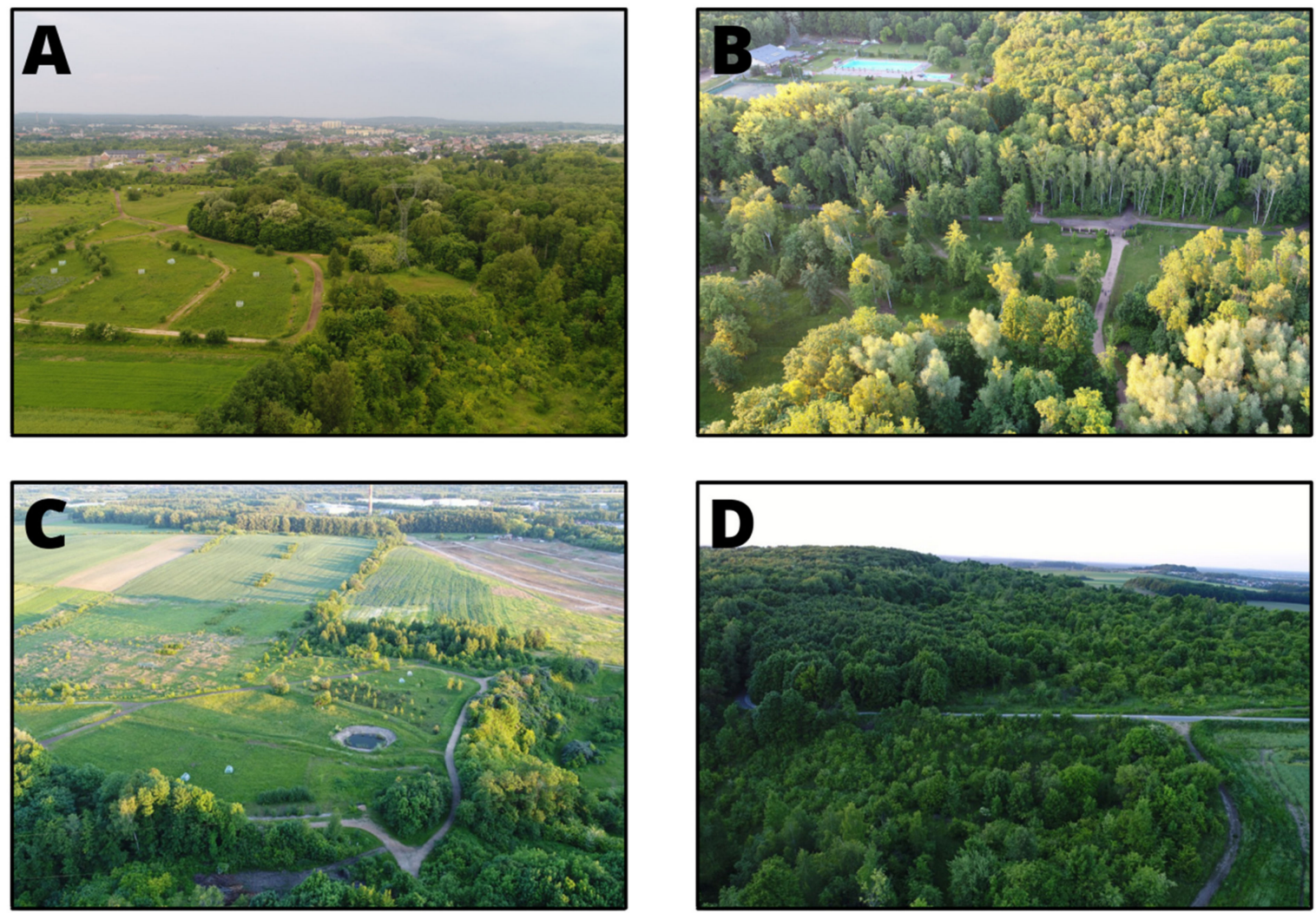

Figure 5. (A-D): (A)—General view of the Silesian Botanical Garden in Radzionków (photos from 9 June 2021). (B)—View of the Regional Ecological Education Station from Ogrodowa Street; (C)-Area of the Silesian Botanical Garden with the habitat collection meadows and marshes; (D) - View of the Księża Góra park north of the Silesian Botanical Garden. Source: own photos. 


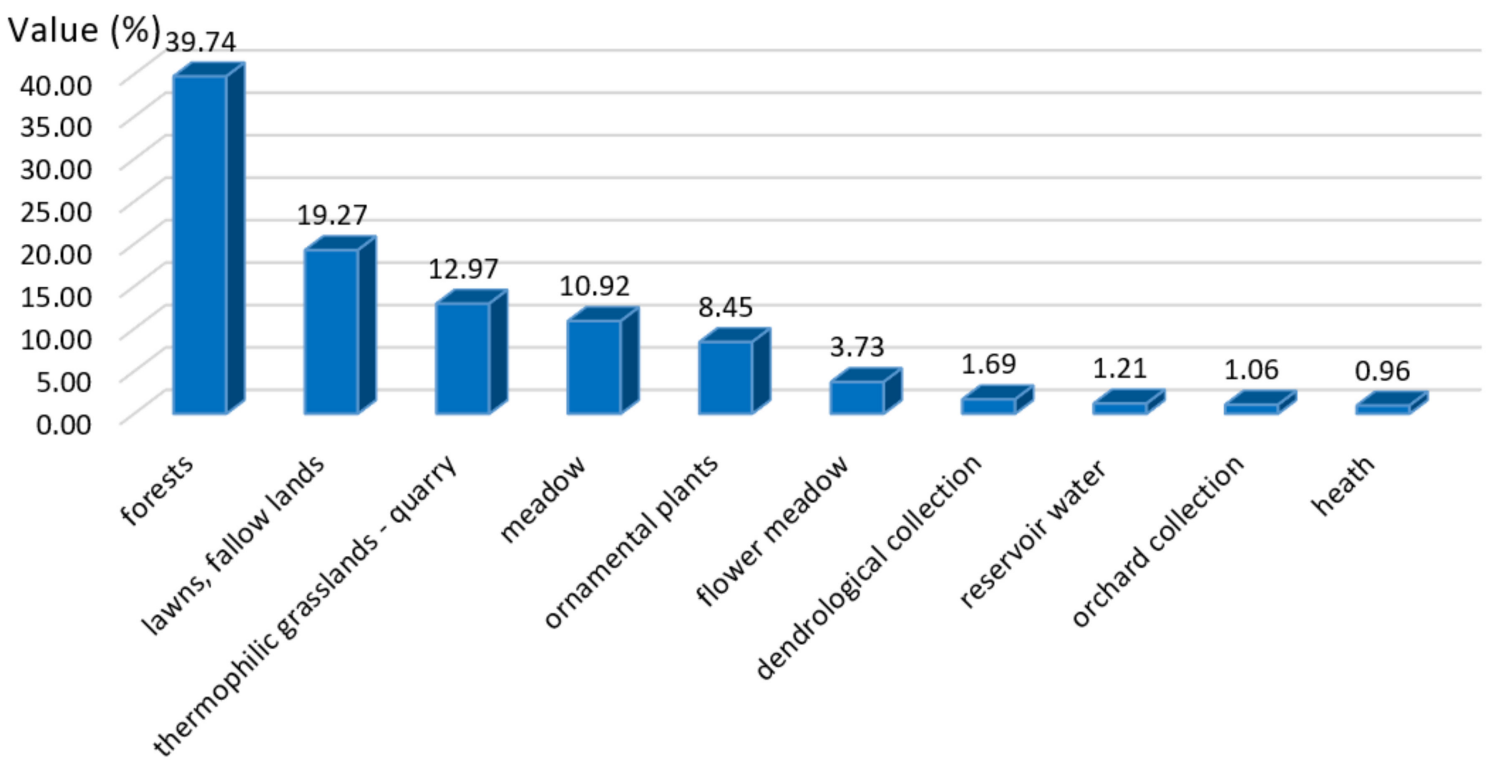

Figure 6. Percentage share of individual forms of land use of the Silesian Botanical Garden. Source: own study based on [102].

In turn, the development of the Silesian Botanical Garden in Mikołów is related to greenfield areas. The history of this garden is associated with many rare and protected plant species in this area [103]. The unique natural environment is created here by the valuable stands of the Fiołkowa Góra, two valleys of the Promna and Jasienica streams, wetlands, and arable fields with increasingly rare protective belts (so-called cleaners), limestone pits, ravines, and hills.

The next natural object occurs in the eastern part of the Katowice conurbation in Jaworzno. It is the GEOsfera Ecological and Geological Education Center. As with the Silesian Botanical Garden in Radzionków, GEOsfera operates on the former limestone quarry site - Sadowa Góra. Placed information boards show the history of this place. It is an area characterized by the richness of Triassic rocks, and the diverse habitat conditions allowed for the formation of a mosaic of plant communities here [104].

Other naturally valuable objects that occur in the Katowice conurbation include, for example, the Municipal Botanical Garden in Zabrze or the Botanical Garden in Brynek. However, the most spectacular example of the development of post-industrial areas is one of the largest city parks in Europe-Silesia Park (until 2012, the Gen. Jerzy Ziętek Provincial Park of Culture and Recreation) in Chorzów. The area of the Silesian Park comprised 75\% of devastating post-industrial areas (heaps, post-mining waste, inferior shafts, sinkholes, swamps, landfills, and agricultural wastelands). One of the main initiators of the creation of the Park was Jerzy Ziętek. Construction began in 1951. The development of the park lasted 18 years [105]. There are many attractions in Silesian Park, including a stadium, a zoo, an amusement park, and a planetarium. Silesia Park "Today it is an example of successful re-vegetation and renaturalization of the anthropogenic landscape" [106] (p. 668).

The above description of the Silesian Botanical Garden shows all the attributes of the green infrastructure concept [15]. The authors point to such elements as:

- urban green infrastructure is viewed, which can be integrated with other urban infrastructures in terms of physical and functional relations (integration);

- green infrastructure planning encompasses the ecological, social, economic, abiotic/biotic, and cultural functions of green spaces; (multifunctionality);

- green infrastructure planning considers physical and functional connections between green spaces at different scales (connectivity);

- green infrastructure can be applied to initiatives at different scales, from individual parcels to the community, regional, and state-level (multi-scale approach) and 
- green infrastructure includes all green and blue spaces, natural and semi-natural areas, water bodies, parks, and gardens (multi-object approach).

Considering the intensity of some of the GI features in the Silesian Botanical Garden, it can even be stated that the small town in which it is located meets these requirements "over-dimensionally."

\section{Discussion}

The example of spatial changes of derelict lands in a small town (Radzionków) located in a large urban region indicates several essential issues. The first is the problem of inter-city competition for investments of regional importance. Radzionków is one of the smaller towns in the Katowice conurbation. The chances of implementing investments of this importance are always relatively small in this case, in part because the city is located on the periphery and has average transport accessibility. The success of the Silesian Botanical Garden location in this city is definitely due to two other factors related to the development of brownfields-the existence of an appropriate (unique) space that could serve as a municipal garden in this case and the proper city management. The uniqueness of the space in which the Silesian Botanical Garden has located results from the fact that it is a former mine of rock raw materials, not the more common brownfield in the Katowice conurbation site of a former coal or sand mine. The specificity of opencast mines of rock raw materials creates a greater chance of obtaining the biodiversity of plant communities, particularly when the development area also includes areas outside the open pit itself. The diversification of the ground, varied topography, and a different degree of earlier transformations $[107,108]$ give great opportunities to achieve the aforementioned effect, which is a value of the Silesian Botanical Garden in Radzionków (also the mentioned GEOsfera in Jaworzno).

Undoubtedly, proper city management was also essential here. Elsewhere [13], an almost model method of creative management of a small city in a large-city setting has been shown. The inter-city competition in a metropolitan region undoubtedly requires appropriate competencies, experience, knowledge, and probably also the appropriate personal characteristics of the mayor (see above).

An equally important problem is local brownfield management policy [109-112]. First of all, one should ask whether this policy in small towns differs from that in large cities. In terms of personnel management, this seems not mentioned in the thread on city management in general. The pro-investment and pro-development policy of the municipal authorities seems to be consistent with good practices regarding derelict lands. The problem may be elsewhere. A small town usually has fewer such areas, and they must be managed wisely, especially when there are various possibilities for their development. Hence, initial decisions as to the directions of brownfield transformations may have a much more significant impact on the further economic and social development of the entire city in the future. In the brownfields analyzed in Radzionków's article, the management of brownfields had a two-way dimension. The areas of liquidated larger industrial plants, including hard coal mines, have been allocated primarily to reindustrialization. Some undeveloped areas related to coal mining and rock mining were developed as green infrastructure (arranged forest, parks, recreational areas) or left as wastelands with a succession of woody species. This model is consistent with the idea that only the best-located and connected degraded areas re-industrialize or develop housing estates. Contaminated areas or areas requiring large financial outlays for infrastructure or that are impossible to develop (active sinkholes, post-mining floodplains) are left for renaturalization.

Radzionków is a good example of successfully transforming an area that is difficult to urbanize or re-industrialize into valuable natural, educational and recreational spaces. Of course, as indicated earlier in the article, the city is not the only one in the region where such natural objects function. However, the development of the Silesian Botanical Garden in Radzionków, in this case, was a "must-be investment." It was most likely the strength and determination of various stakeholders that resulted in the aforementioned 
green infrastructure model effect. The determination to create the Silesian Botanical Garden was even more important as this facility is part of a network of educational and cognitive institutions (the Museum of Bread, the Center for Documentation of the Deportation of Upper Silesians to the USSR in 1945). For a city that is losing its heritage of operating as a mining center for 200 years, this is an essential element of development and protects it from "the place that does not matter" syndrome [113].

From the point of spatial development, the Silesian Botanical Garden has one more characteristic feature. This area is the largest brownfield in the city, which has gained a new function-a greening area. This transformation is also significant from the city's sustainable development [58]. It seems that in the search for the idea of a sustainable city, such a space has a stimulating value.

\section{Conclusions}

The article examines the development of the Silesian Botanical Garden in Radzionków in a small town in the south of Poland. On the one hand, this object is an example of the form of development of post-industrial areas. On the other hand, it acts as an essential element of local policy at the turning point of the socio-economic transformation. It was presented in the publication that this kind of green infrastructure, such as botanical gardens in favorable location conditions, might constitute an essential element of activation of small towns in the event of loss or reduction of existing economic and social functions. The article also emphasizes the role of local leaders and their competencies as stimulants of the city revitalization process but implemented by the assumptions of social responsibility. In small towns, such as the analyzed Radzionków, there is an emphasis on a well-thought-out policy towards brownfields, based on "one-off" decision accuracy. The green infrastructure, such as the Silesian Botanical Garden, also indicates that they can be an essential element of spatial development for a large urban region and not just for one city. In the analyzed case, it was possible to weave this area and the institution into a local cultural and educational network. The example of the spatial development of a small post-mining town in southern Poland discussed in the article confirms the legitimacy of defining such areas as elements of the concept of green infrastructure. The analyzed example contains all the elements and the complexity of this concept.

Nevertheless, the conducted research indicates the need for further analysis, particularly regarding competition for space, governance, or a possible "excess" of investments of this type in the region. The success of the land use policy in Radzionków, which created the Silesian Botanical Garden, is a starting point and an example, especially for smaller cities near a large metropolis.

Author Contributions: Conceptualization, I.K.-P.; methodology, I.K.-P., A.Z. and J.B.; software, A.Z. and J.B.; validation, A.Z. and J.B.; formal analysis, I.K.-P., A.Z. and J.B.; investigation, I.K.-P., A.Z. and J.B.; resources, A.Z. and J.B.; data curation, A.Z. and J.B.; writing-original draft preparation, I.K.-P.; writing-review and editing, I.K.-P.; visualization, A.Z. and J.B.; supervision, I.K.-P. All authors have read and agreed to the published version of the manuscript.

Funding: This research received no external funding.

Institutional Review Board Statement: Not applicable.

Informed Consent Statement: Not applicable.

Data Availability Statement: The data presented in this study are available on request from the corresponding author.

Conflicts of Interest: The authors declare no conflict of interest. 


\section{References}

1. Martinez-Fernandez, C.; Wu, C.-T.; Schatz, L.K.; Taira, N.; Vargas-Hernández, J.G. The shrinking mining city: Urban dynamics and contested territory. Int. J. Urban. Reg. Res. 2012, 36, 245-260. [CrossRef] [PubMed]

2. Haase, A.; Rink, D.; Grossmann, K.; Bernt, M.; Mykhnenko, V. Conceptualizing Urban Shrinkage. Environ. Plan. A Econ. Space 2014, 46, 1519-1534. [CrossRef]

3. Batunova, E.; Gunko, M. Urban shrinkage: An unspoken challenge of spatial planning in Russian small and medium-sized cities. Eur. Plan. Stud. 2018, 26, 1580-1597. [CrossRef]

4. Tong, Y.; Liu, W.; Li, C.; Zhang, J.; Ma, Z. Small towns shrinkage in the Jilin Province: A comparison between China and developed countries. PLoS ONE 2020, 15, e0231159. [CrossRef]

5. Tong, Y.; Liu, W.; Li, C.; Zhang, J.; Ma, Z. Understanding patterns and multilevel influencing factors of small town shrinkage in Northeast China. Sustain. Cities Soc. 2021, 68, 102811. [CrossRef]

6. Wiechmann, T.; Pallagst, K. Urban shrinkage in Germany and the USA: A comparison of transformation patterns and local strategies. Int. J. Urban Reg. Res. 2012, 36, 261-280. [CrossRef]

7. Atkinson, R. Policies for small and medium-sized towns: European, national and local approaches. Tijdschr. Econ. Soc. Geogr. 2017, 108, 472-487. [CrossRef]

8. Kantor-Pietraga, I. Does one decade of urban policy for the shrinking city make visible progress in urban re-urbanization? A case study of bytom, Poland. Sustainability 2021, 13, 4408. [CrossRef]

9. Wirth, P.; Elis, V.; Müller, B.; Yamamoto, K. Peripheralisation of small towns in Germany and Japan-Dealing with economic decline and population loss. J. Rural Stud. 2016, 47, 62-75. [CrossRef]

10. Lovell, S.A.; Gray, A.; Boucher, S.E. Economic marginalization and community capacity: How does industry closure in a small town affect perceptions of place? J. Rural Stud. 2018, 62, 107-115. [CrossRef]

11. Mayer, H.; Knox, P. Small-town sustainability: Prospects in the second modernity. Eur. Plan. Stud. 2010, 18, 1545-1565. [CrossRef]

12. Szeligova, N.; Teichmann, M.; Kuda, F. Research of the disparities in the process of revitalization of brownfields in small towns and cities. Sustainability 2021, 13, 1232. [CrossRef]

13. Krzysztofik, R.; Kantor-Pietraga, I.; Kłosowski, F. Between Industrialism and Postindustrialism-The Case of Small Towns in a Large Urban Region: The Katowice Conurbation, Poland. Urban Sci. 2019, 3, 68. [CrossRef]

14. Mell, I.C. Green Infrastructure: Concepts and planning. FORUM E-J. 2008, 8, 69-80.

15. Wirth, P.; Chang, J.; Syrbe, R.U.; Wende, W.; Hu, T. Green infrastructure: A planning concept for the urban transformation of former coal-mining cities. Int. J. Coal Sci. Technol. 2018, 5, 78-91. [CrossRef]

16. De Sousa, C.A. The greening of brownfields in American cities. J. Environ. Plan. Manag. 2004, 47, 579-600. [CrossRef]

17. Chang, J.; Koetter, T. From abandoned mine land to landscape park. J. China Coal Soc. 2005, 30, 399-402.

18. Siikamäki, J.; Wernstedt, K. Turning brownfields into greenspaces: Examining incentives and barriers to revitalization. J. Health Polit. Policy Law 2008, 33, 559-593. [CrossRef]

19. Kristiánová, K.; Gécová, K.; Putrová, E. Old Industrial Sites-Conversion to Parks: Potential of Bratislava. Proc. Eng. 2016, 161, 1858-1862. [CrossRef]

20. Rizzo, E.; Pesce, M.; Pizzol, L.; Alexandrescu, F.M.; Giubilato, E.; Critto, A.; Marcomini, A.; Bartke, S. Brownfield regeneration in Europe: Identifying stakeholder perceptions, concerns, attitudes and information needs. Land Use Policy 2015, 48, 437-453. [CrossRef]

21. Tkacz, K. Rewitalizacja terenów KWB “Bełchatów” jako szansa na rozwój małych miast. Revitalization of Coal Mine Belchatow, as an opportunity for the development of small towns. Przestrz. Forma 2015, 23, 267-278. Available online: http://yadda.icm.edu. pl/baztech/element/bwmeta1.element.baztech-fab3b922-a795-4beb-80b1-6a8e290d7157 (accessed on 10 May 2021).

22. Navratil, J.; Picha, K.; Martinat, S.; Nathanail, P.C.; Tureckova, K.; Holesinska, A. Resident's preferences for urban brownfield revitalization: Insights from two Czech cities. Land Use Policy 2018, 76, 224-234. [CrossRef]

23. BenDor, T.K.; Metcalf, S.S.; Paich, M. The dynamics of brownfield redevelopment. Sustainability 2011, 3, 914-936. [CrossRef]

24. Lazzeroni, M. Industrial decline and resilience in small towns: Evidence from three European case studies. Tijdschr. Econ. Soc. Geogr. 2020, 111, 182-195. [CrossRef]

25. Heder, A.; Tkocz, M. Zmiany demograficzne i funkcjonalne małych miast górniczych (na przykładzie Bierunia i Lędzin) Demographic and functional changes in small mining towns (on the example of Bierun and Lędzin). Acta Geogr. Sil. 2011, 10, 11-20. Available online: https:/ / core.ac.uk/download/pdf/197753213.pdf (accessed on 12 May 2021).

26. Vaishar, A.; Lipovská, Z.; Št'astná, M. Small towns in post-mining regions. In Post-Mining Regions in Central Europe Problems, Potentials, Possibilities; Wirth, P., Mali, B.Č., Fischer, W., Eds.; Oekom: München, Germany, 2012; pp. $153-167$.

27. Marais, L.; Atkinson, D. Towards a post-mining economy in a small town: Challenges, obstacles and trends. In Proceedings of the Desert Knowledge Australia Conference, Alice Springs, Australia, 3-6 November 2006.

28. Prach, K.; Řehounková, K.; Řehounek, J.; Konvalinková, P. Ecological restoration of central european mining sites: A summary of a multi-site analysis. Landsc. Res. 2011, 36, 263-268. [CrossRef]

29. Adesipo, A.A.; Freese, D.; Zerbe, S.; Wiegleb, G. An approach to thresholds for evaluating post-mining site reclamation. Sustainability 2021, 13, 5618. [CrossRef]

30. Marot, N.; Harfst, J. Post-mining potentials and redevelopment of former mining regions in Central Europe-Case studies from Germany and Slovenia. Acta Geogr. Slov. 2012, 52, 99-119. [CrossRef] 
31. Kaźmierczak, U.; Strzałkowski, P.; Lorenc, M.W.; Szumska, E.; Sánchez, A.A.P.; Baker, K.A.C. Post-mining Remnants and Revitalization. Geoheritage 2019, 11, 2025-2044. [CrossRef]

32. Łacny, Z.; Kowalska, N.; Tran, L. The Possibilities of the Revitalisation of Post-Mining Areas-the Polish and Vietnamese Examples. Inż. Miner. 2019, 13. [CrossRef]

33. Krzysztofik, R.; Runge, J.; Kantor-Pietraga, I. Paths of Environmental and Economic Reclamation: The Case of Post-Mining Brownfields. Pol. J. Environ. Stud. 2012, 21, 219-223. Available online: http:/ / www.pjoes.com/Paths-of-Environmental-andEconomic-r-nReclamation-the-Case-of-Post-Mining-Brownfields, 88745,0,2.html (accessed on 12 May 2021).

34. Görmar, F.; Harfst, J. Path renewal or path dependence? The role of industrial culture in regional restructuring. Urban Sci. 2019, 3, 106. [CrossRef]

35. Boros, L.; Martyin, Z.; Pál, V. Industrial tourism-trends and opportunities. Forum Geogr. 2013, 12, 108-114. [CrossRef]

36. Syrbe, R.U. Recultivation and sustainable development of post-mining landscapes. In Legislation, Technology and Practice of Mine Land Reclamation; Hu, Z.Q., Ed.; CRC Press: London, UK, 2015; pp. 489-492.

37. Chang, J.; Feng, S. Strategies on redevelopment of mining city industrial wasteland. Urban. Dev. Stud. 2008, 2, 54-57.

38. Konecka-Szydłowska, B. Szanse i zagrożenia rozwoju nowo utworzonych małych miast. Stud. Miej. 2020, 7, 123-134. Available online: https:/ / czasopisma.uni.opole.pl/index.php/sm/article/view/2652 (accessed on 13 May 2021).

39. Loures, L. Post-industrial landscapes as drivers for urban redevelopment: Public versus expert perspectives towards the benefits and barriers of the reuse of post-industrial sites in urban areas. Habitat Int. 2015, 45, 72-81. [CrossRef]

40. Loures, L.; Vaz, E. Exploring expert perception towards brownfield redevelopment benefits according to their typology. Habitat Int. 2018, 72, 66-76. [CrossRef]

41. Courtney, P.; Errington, A. The Role of small towns in the local economy and some implications for development policy. Local Econ. 2000, 15, 280-301. [CrossRef]

42. Zuzańska-Żyśko, E. Małe miasta w strefie oddziaływania ośrodków regionalnych. Small towns in the area of influence of regional centers. Biul. PAN. Kom. Przestrz. Zagospod. Kraj. 2007, 232, 62-78.

43. Kwiatek-Sołtys, A. The role of small towns in the metropolitan areas. In Desafios de Las Metropolis: Efectos Ambientales y Sociales: Tendencias Geográficas II; Santana-Juárez, M.V., Hoyos-Castrillo, G., Santana-Castańeda, G., Pineda-Jaimes, N.B., Campos-Alanís, H., Eds.; Universidad Autónoma del Estado de México: Toluca, Mexico, 2016; pp. 443-454.

44. Gałka, J.; Warych-Juras, A. Suburbanization and migration in polish metropolitan areas during political transition. Acta Geogr. Slov. 2018, 58, 63-72. [CrossRef]

45. Majewska, A.; Denis, M.; Krupowicz, W. Urbanization Chaos of suburban small cities in Poland: 'Tetris development'. Land 2020, 9, 461. [CrossRef]

46. Krzysztofik, R. (Ed.) Przemiany Demograficzne Miast Polski. Wymiar Krajowy, Regionalny i Lokalny. Demographic Changes in Polish Cities. National, Regional and Local Dimension; Instytut Rozwoju Miast i Regionów: Warszawa-Kraków, Poland, 2019.

47. Wolff, M.; Wiechmann, T. Urban growth and decline: Europe's shrinking cities in a comparative perspective 1990-2010. Eur. Urban Reg. Stud. 2018, 25, 122-139. [CrossRef]

48. Pallagst, K.; Wiechmann, T.; Martinez-Fernandez, C. (Eds.) Shrinking Cities. International Perspectives and Policy Implications; Routledge: New York, NY, USA, 2013.

49. Mallach, A.; Haase, A.; Hattori, K. The shrinking city in comparative perspective: Contrasting dynamics and responses to urban shrinkage. Cities 2017, 69, 102-108. [CrossRef]

50. Batunova, E.; Perucca, G. Population shrinkage and economic growth in Russian regions 1998-2012. Reg. Sci. Policy Pract. 2019, 12, 595-609. [CrossRef]

51. Döringer, S.; Uchiyama, Y.; Penker, M.; Kohsaka, R. A meta-analysis of shrinking cities in Europe and Japan. Towards an integrative research agenda. Eur. Plan. Stud. 2019, 28, 1693-1712. [CrossRef]

52. Stryjakiewicz, T. (Ed.) Kurczenie się Miast w Europie Środkowo-Wschodniej. Urban. Shrinkage in Towns of the Central and East. Europe; Bogucki Wydawnictwo Naukowe: Poznań, Poland, 2014.

53. Ženka, J.; Krtička, L.; Paszová, L.; Pundová, T.; Rudincová, K.; Št’astná, S.; Svetlíková, V.; Matula, J. Micro-Geographies of Information and communication technology firms in a shrinking medium-sized industrial City of Ostrava (Czechia). Land 2021, 10, 695. [CrossRef]

54. Bontje, M. Facing the challenge of shrinking cities in East Germany: The case of Leipzig. GeoJournal 2004, 61, 13-21. [CrossRef]

55. Bartholomae, F.; Nam, C.W.; Schoenberg, A. Urban shrinkage and resurgence in Germany. Urban Stud. 2017, 54, 2701-2718. [CrossRef]

56. Nelle, A.; Großmann, K.; Haase, D.; Kabisch, S.; Rink, D.; Wolff, M. Urban shrinkage in Germany: An entangled web of conditions, debates and policies. Cities 2017, 69, 116-123. [CrossRef]

57. Frantál, B.; Greer-Wootten, B.; Klusáček, P.; Krejčí, T.; Kunc, J.; Martinát, S. Exploring spatial patterns of urban brownfields regeneration: The case of Brno, Czech Republic. Cities 2015, 44, 9-18. [CrossRef]

58. Mert, Y. Contribution to sustainable development: Redevelopment of post-mining brownfields. J. Clean. Prod. 2019, $240,118212$. [CrossRef]

59. Pytel, S.; Sitek, S.; Chmielewska, M.; Zuzańska-Żyśko, E.; Runge, A.; Markiewicz-Patkowska, J. Transformation directions of brownfields: The case of the Górnośląsko-Zagłębiowska Metropolis. Sustainability 2021, 13, 2075. [CrossRef] 
60. De Groot, R.S.; Alkemade, R.; Braat, L.; Hein, L.; Willemen, L. Challenges in integrating the concept of ecosystem services and values in landscape planning, management and decision making. Ecol. Complex 2010, 7, 260-272. [CrossRef]

61. Connop, S.; Vandergert, P.; Eisenberg, B.; Collier, M.J.; Nash, C.; Clough, J.; Newport, D. Renaturing cities using a regionallyfocused biodiversity-led multifunctional benefits approach to urban green infrastructure. Environ. Sci. Pol. 2016, 62, 99-111. [CrossRef]

62. Rosa, J.C.S.; Sánchez, L.E.; Morrison-Saunders, A. Getting to 'agreed' post-mining land use-an ecosystem services approach. Impact Assess. Proj. Apprais. 2018, 36, 220-229. [CrossRef]

63. Sonter, L.J.; Ali, S.H.; Waston, J.E.M. Mining and biodiversity: Key issues and research needs in conservation science. Proc. Biol. Sci. 2018, 285, 20181926. [CrossRef]

64. Łopucki, R.; Klich, D.; Kitowski, I.; Kiersztyn, A. Urban size effect on biodiversity: The need for a conceptual framework for the implementation of urban policy for small cities. Cities 2020, 98, 102590. [CrossRef]

65. Almenar, J.B.; Elliot, T.; Rugani, B.; Philippe, B.; Gutierrez, T.N.; Sonnemann, G.; Geneletti, D. Nexus between nature-based solutions, ecosystem services and urban challenges. Land Use Policy 2021, 100, 104898. [CrossRef]

66. Chmielewska, M.; Lamparska, M. Post-industrial tourism as a chance to develop cities in traditional industrial regions in Europe. Sociol. Românească 2011, 3, 67-75.

67. Horváth, G.; Csüllög, G. The Role of Ecotourism and Geoheritage in the Spatial Development of Former Mining Regions. In Post-Mining Regions in Central Europe Problems, Potentials, Possibilities; Wirth, P., Mali, B.Č., Fischer, W., Eds.; Oekom: München, Germany, 2012; pp. 226-240.

68. Pavolová, H.; Kysel'ová, K.; Bakalár, T. Brownfields as a tool for support of Destination Tourism development. Acta Geotur. 2012, 3, 26-30. Available online: https:/ /geotur.tuke.sk/pdf/2012/n01/04_Pavolova_v3_n1.pdf (accessed on 18 May 2021).

69. Gregorová, B.; Hronček, P.; Tometzová, D.; Molokáč, M.; Čech, V. Transforming brownfields as tourism destinations and their sustainability on the example of Slovakia. Sustainability 2020, 12, 10569. [CrossRef]

70. Hansen, R.; Pauleit, S. From multifunctionality to multiple ecosystem services? A conceptual framework for multifunctionality in green infrastructure planning for Urban Areas. AMBIO 2014, 43, 516-529. [CrossRef]

71. Keyes, R. Mine closures in Canada: Problems, Prospects and Policies. In Coping with Closure: An International Comparison of Mine Town Experiences; Neil, C., Tykkläinen, M., Bradbury, J., Eds.; Routledge: London, UK; New York, NY, USA, 1992 ; pp. $27-43$.

72. Smyth, R.; Mishra, V.; Qian, X. The Environment and Well-Being in Urban China. Ecol. Econ. 2008, 68, 547-555. [CrossRef] [PubMed]

73. Pauleit, S.; Liu, L.; Ahern, J.; Kazmierczak, A. Multifunctional green infrastructure planning to promote ecological services in the city. In Urban Ecology: Patterns, Processes, and Applications; Niemelä, J., Ed.; Oxford University Press: New York, NY, USA, 2011; pp. 272-285.

74. Doley, D.; Audet, P. What part of mining are ecosystems? Defining success for the 'restoration'of highly disturbed landscapes. In Ecological Restoration: Global Challenges, Social Aspects and Environmental Benefits; Squires, V.R., Ed.; Nova Science: New York, NY, USA, 2016; pp. 57-88.

75. Mapa Topograficzna. Topographic Map. Meßtischblatt 5579: Tarnowitz. 1940. Available online: http://amzpbig.com/maps/02 5_TK25/5579_Tarnowitz_mz_1940.jpg (accessed on 6 April 2021).

76. Mapa Topograficzna. Topographic Map. Meßtischblatt 5579: Tarnowitz. 1943. Available online: http://amzpbig.com/maps/02 5_TK25/5579_Tarnowitz_1943.jpg (accessed on 6 April 2021).

77. Mapa Topograficzna. Topographic Map. Meßtischblatt 5679: Beuthen. 1934. Available online: http://amzpbig.com/maps/025_ TK25/5679_Beuthen_1934.jpg (accessed on 6 April 2021).

78. Mapa Topograficzna. Topographic Map. Meßtischblatt 5679: Beuthen. 1943. Available online: http://amzpbig.com/maps/025_ TK25/5679_Beuthen_1943.jpg (accessed on 6 April 2021).

79. Corine Land Cover 2018 PL. Available online: https://clc.gios.gov.pl/index.php/clc-2018/metadane (accessed on 30 March 2021).

80. Urban Atlas 2018 Copernicus Land Monitoring Service. Available online: https://land.copernicus.eu/local/urban-atlas/urbanatlas-2018 (accessed on 30 March 2021).

81. Google Maps. Available online: https://www.google.pl/maps (accessed on 6 April 2021).

82. OpenStreetMap. Available online: https://www.openstreetmap.org/ (accessed on 6 April 2021).

83. Geoportal 2 Mapy. Geoportal 2 Maps. Available online: https://mapy.geoportal.gov.pl/ (accessed on 6 April 2021).

84. Jaros, J. Tajemnice Górnoślaskich Koncernów [Mystery of Upper Silesian Concerns]; Śląski Instytut Naukowy: Katowice, Poland, 1988.

85. Mrowiec, A. Dzieje Kopalni Węgla Kamiennego, Radzionków" w Radzionkowie (1871-1971). The History of the "Radzionków" Hard Coal Mine in Radzionków (1871-1971); Zakłady Graficzne Przemysłu Węglowego: Katowice, Poland, 1972.

86. Krawczyk, J.A.; Minas, M.; Tyczka, P.; Wroński, J. Dzieje Radzionkowa. The History of Radzionków. Wydawnictwo Rococo; Urząd Miasta Radzionków: Radzionków, Poland, 2002.

87. Tobor, G. Development of Post-Industrial Areas in the Mining Commune of Radzionków in the Years 1998-2003; Towarzystwo Naukowe Organizacji i Kierownictwa: Katowice, Poland, 2003. (In Polish)

88. Bank Danych Lokalnych [Local Data Bank]. Główny Urząd Statystyczny w Polsce. Statistics Poland. Available online: https: // bdl.stat.gov.pl/BDL/start (accessed on 1 July 2021). 
89. GUGiK Baza Danych Obiektów Topograficznych. Topographic Objects Database. Available online: http://www.gugik.gov.pl/ pzgik/inne-dane-udostepniane-bezplatnie (accessed on 5 May 2021).

90. A Study on Conditions and Directions of Spatial Development of the Radzionków Municipality. 2017. Available online: http:/ / bip.radzionkow.pl/?c=337 (accessed on 20 April 2021). (In Polish).

91. Development Strategy of the Radzionków Commune for 2014-2025. 2014. Available online: http:/ / bip.radzionkow.pl/?c=2363 (accessed on 4 May 2021). (In Polish).

92. Communal Strategy for Solving Social Problems of the City of Radzionków for 2011-2020. 2010. Available online: http: / / bip.radzionkow.pl/ ?a=27677 (accessed on 6 May 2021). (In Polish).

93. Low Emission Reduction Program for the Radzionków Commune for 2019-2021. 2019. Available online: http:/ / bip.radzionkow. $\mathrm{pl} / \mathrm{?}=24165$ (accessed on 6 May 2021). (In Polish).

94. Environmental Protection Program for the Radzionków Commune until 2020. 2015. Available online: http:// bip.radzionkow.pl/ ?a=17667 (accessed on 10 May 2021). (In Polish).

95. Sustainable Urban Mobility Plan in the Radzionków Commune. 2015. Available online: http://bip.radzionkow.pl/?a=21074 (accessed on 13 May 2021). (In Polish).

96. Commune Revitalization Program for the Radzionków Commune. 2017. Available online: http://bip.radzionkow.pl/?a=20035 (accessed on 13 May 2021). (In Polish).

97. Brandenburg, H.; Tobor, G. Problemy Rewitalizacji Obszarów Zdegradowanych Małych Miast na Przykładzie Miasta Radzionków. Problems related to the Revitalization of Degraded Areas of Small Towns Illustrated on the Example of Radzionków. Pr. Nauk. UE Wrocław. 2018, 502, 11-21. Available online: https://www.dbc.wroc.pl/Content/41080/Brandenburg_Problemy_Rewitalizacji_ Obszarow_Zdegradowanych_Malych_2018.pdf (accessed on 20 May 2021).

98. Mihaylov, V.; Runge, J.; Krzysztofik, R.; Spórna, T. Paths of evolution of territorial identity. The case of former towns in the katowice conurbation. Geogr. Pannon. 2019, 23, 173-184. [CrossRef]

99. Spórna, T. The suburbanisation process in a depopulation context in the Katowice conurbation, Poland. Environ. Socio-Econ. Stud. 2018, 6, 57-72. [CrossRef]

100. Spórna, T.; Krzysztofik, R. Inner' suburbanisation-Background of the phenomenon in a polycentric, post-socialist and postindustrial region. Example from the Katowice conurbation, Poland. Cities 2020, 104, 102789. [CrossRef]

101. Silesian Botanical Garden in Radzionków. Available online: https://visiton.pl/en/miejsca-atrakcje-zabytki/parki-krajobrazowe/ ad/6137-slaski-ogrod-botaniczny-w-radzionkowie.html (accessed on 31 May 2021).

102. Silesian Botanical Garden in Radzionków. Available online: www.obradzionkow.robia.pl (accessed on 3 July 2021). (In Polish).

103. Kojs, P. The Silesian Botanical Garden as a Natural Habitat Garden. BGjournal 2009, 6, 20-22. Available online: https://www.jstor. org/stable/bgj.6.1.20 (accessed on 24 May 2021).

104. Bieniek, B.; Kordysh, A.; Mirosławski, M.; Nowak, K.; Sękowski, K.; Sierka, E. Geoproduct potential analysis based on the example of the GEOsfera Ecological and Geological Education Center in Jaworzno. Geotourism 2019, 16, 29-37. [CrossRef]

105. Łukaszkiewicz, J.; Fortuna-Antoszkiewicz, B. Silesia Park in Chorzów/Poland-the successful re-naturalization of industrial landscape after 60-years. Miškininkystè Ir Kraštotvarka For. Landsc. Manag. 2017, 1, 25-34. Available online: http:/ /www.kmaik.lt/ uploads/BIBLIOTEKA/MK/2017_1(12).pdf (accessed on 24 May 2021).

106. Łukaszkiewicz, J.; Fortuna-Antoszkiewicz, B.; Długoński, A.; Wiśniewski, P. From the heap to the park-reclamation and adaptation of degraded urban areas for recreational functions in Poland. Sci. Rev. Eng. Environ. Sci. 2019, 28, 664-681. [CrossRef]

107. Rahmonov, O.; Krzysztofik, R.; Środek, D.; Smolarek-Lach, J. Vegetation- and environmental changes on non-reclaimed spoil heaps in Southern Poland. Biology 2020, 9, 164. [CrossRef]

108. Abramowicz, A.; Rahmonov, O.; Chybiorz, R. Environmental management and landscape transformation on self-heating coal-waste dumps in the upper silesian Coal Basin. Land 2021, 10, 23. [CrossRef]

109. Franz, M.; Güles, O.; Prey, G. Place-Making and 'Green' Reuses of Brownfields in the Ruhr. Tijdschr. Econ. Soc. Geogr. 2008, 99, 316-328. [CrossRef]

110. Andres, L. Levels of Governance and Multi-stage Policy Process of Brownfield Regeneration: A Comparison of France and Switzerland. Int. Plan. Stud. 2012, 17, 23-43. [CrossRef]

111. Harfst, J.; Wirth, P.; Lintz, G. Governing post-mining potentials: The role of regional capacities. In Post-Mining Regions in Central Europe Problems, Potentials, Possibilities; Wirth, P., Mali, B.Č., Fischer, W., Eds.; Oekom: München, Germany, $2012 ;$ pp. $168-181$.

112. Klusáček, P.; Alexandrescu, F.; Osman, R.; Malý, J.; Kunc, J.; Dvořák, P.; Frantál, B.; Havlíček, M.; Krejčí, T.; Martinát, S.; et al. Good governance as a strategic choice in brownfield regeneration: Regional dynamics from the Czech Republic. Land Use Policy 2018, 73, 29-39. [CrossRef]

113. Rodríguez-Pose, A. The revenge of the places that don't matter (and what to do about it). Camb. J. Reg. Econ. Soc. 2018, 11, 189-209. [CrossRef] 